Volume 12, Nomor 2, April 2021, p.022-035

Faculty of Law, Universitas Kristen Maranatha

ISSN: 2085-9945 I e-ISSN: 2579-3520

Nationally Accredited Journal by SINTA

\title{
PERLINDUNGAN HUKUM TERHADAP PEMILIK MEREK TIDAK TERDAFTAR DITINJAU DARI PRINSIP USE IN COMMERCE
}

\author{
Yohan Prawira Pakpahan, Imam Haryanto \\ Fakultas Hukum, Universitas Pembangunan Nasional Veteran Jakarta \\ yohanprawirap@upnvj.ac.id, imam.upns1@gmail.com
}

Submitted: 2021-01-26 | Reviewed: 2021-02-24| Accepted: 2021-04-13

How to cite: Yohan Prawira Pakpahan. Imam Haryanto, "Perlindungan Hukum terhadap Pemilik Merek Tidak Terdaftar Ditinjau dari Prinsip Use in Commerce". Dialogia Iuridica: Jurnal Hukum Bisnis dan Investasi, Vol. 12, No. 2, (2021): 022-035.

\section{DOI:}

https://doi.org/10.28932/di.v12i2.3337

\section{ABSTRACT}

A trademark may be a sign that features a distinguishing power and is employed within the context of trading goods or services. In Indonesia, trademarks are protected supported the primary registrant protection system or constitutive principle. The protection system states that a protected brand may be a trademark that has been registered with the Directorate General of belongings or trademarks declared as well-known trademark. The matter that happens is said as to whether there's protection for ordinary trademark that don't seem to be registered when there are parties who aren't accountable for registering the trademark, in order that the rights to the trademark are given to parties who aren't the particular owners of the trademark. This suggests that the law only provides protection to the primary person to register. Supported that, they get the exclusive rights and show that they're truth owner. Situation like this protects false registration and provides false protection. The trademark protection mechanism in America doesn't implement this type of protection. America uses the protection supported the utilization 
as a practical, which is should fulfill the necessities, prefer it should be employed in commerce or will be utilized in commerce. For trademarks that haven't yet been registered, Indonesia should implement a protection system implemented by the United States. that helps protect unregistered trademarks if they need been utilized in trade.

Keywords: Constitutive Principle; Trademarks; Use in Commerce.

\section{PENDAHULUAN}

Perdagangan adalah salah satu aspek vital dalam pertumbuhan ekonomi di Indonesia. Setiap pelaku usaha didorong untuk berinovasi tanpa henti, agar produk maupun jasa mereka tetap eksis di pasar yang setiap hari semakin ketat persaingannya. Dalam konteks inovasi atas produk maupun jasa, tentunya pelaku usaha tidak ingin ciptaannya ditiru, diimitasi, dan dibajak oleh pihak yang tidak bertanggung jawab. Perkara menimpa Hak Kekayaan intelektual hendak meramba berbagai aspek teknologi, industri, sosial, budaya, serta berbagai aspek yang ada. Hukum diharapkan dapat menangani bermacam perkara yang muncul berkaitan dengan Hak Kekayaan intelektual tersebut. Hukum wajib dapat membagikan perlindungan untuk karya intelektual, agar dapat meningkatkan daya kreasi penduduk yang akhirnya bermuara pada tujuan berhasilnya proteksi hak kekayaan intelektual. Hukum kekayaan intektual bertabiat asing untuk kepercayaan yang mendasari hukum adat, sehingga tampaknya besar tidak akan mempengaruhi atau terdapat pengaruh terhadap mayoritas daerah di Indonesia. Tentang inilah yang barangkali menjadi halangan terbanyak yang dapat meletigmasi penolakan terhadap kekayaan intelektual di Indonesia yakni konsep yang telah lama diakui mayoritas masyarakat Indonesia yang cocok dengan hukum adat. Oleh karena itu timbul kebutuhan dari pelaku usaha untuk memiliki suatu identitas atau keunikan yang sangat kental terhadap setiap ciptaan yang diproduksinya, yaitu merek.

Dalam dunia perdagangan, kerapkali berlangsung tindakan-tindakan yang bertujuan untuk mencari keuntungan sendiri dengan teknik apapun yang dapat berdampak kerugian untuk pihak lain. Merek selaku suatu indikasi yang cukup berguna untuk diketahui oleh para konsumen, kerapkali dijadikan alat untuk mencari keuntungan dengan mudah, dengan meniru, maupun berusaha untuk memalsukan merek- merek yang telah terkemuka di publik. Oleh sebab itu, syarat mengenai hak kekayaan intelektual, eksklusifnya merek di Indonesia serta Amerika Serikat bersama sudah membagikan perlindungan terhadap pemegang merek. Negeri Indonesia serta Amerika Serikat bersama membagikan proteksi hukum terhadap pemegang merek. 
Tetapi, ada perbandingan dalam perihal pengambilan langkah- langkah dalam membagikan perlindungan hukum. Indonesia berpendapat terdapatnya suatu pelanggaran apabila terdapatnya aduan dari pihak yang merasa dirugikan. Berbeda dengan Amerika Serikat, dimana tidak hanya dengan adanya aduan dari pihak yang dirugikan, pemerintah serta petugas yang berwenang serta berfungsi penting dalam menerapkan penghindaran, pembasmian serta perlindungan terhadap pemegang merek. Terdapatnya persamaan dan perbandingan dalam perlindungan hukum ini, menciptakan setiap negeri memiliki sisi positif dan negatif dalam melindungi merek tersebut.

Merek memiliki sekian banyak peranan, yakni selaku "badge of origin, a piece of personal property, and cultural resource". Merek selaku “badge of origin", menggambarkan hak bernilai dalam perdagangan serta memperlihatkan ikatan erat antara benda, jasa dan orang yang memiliki merek tersebut dengan asal benda, sebaliknya "personal property", memiliki makna jika merek menggambarkan peninggalan untuk pemilik merek, sehingga pemilik merek sanggup menjual merek tersebut sebab mempunyai nilai ekonomi, sebaliknya merek selaku "cultural resource", adalah merek sanggup bersinggungan dengan budaya suatu negara, misalnya "Barbie" sebuah produk boneka yang merepresentasikan budaya Amerika Serikat. Menurut Abdul Kadir, merek memiliki peranan:

1. Bagaikan indikasi pengenal untuk membedakan hasil penciptaan yang dihasilkan seseorang maupun sebagian orang secara bersama- sama ataupun badan hukum dengan penciptaan orang lain ataupun badan hukum yang lain.

2. Bagaikan alat promosi, sehingga mempromosikan hasil penciptaan cukup dengan menyebut mereknya.

3. Bagaikan jaminan atas kualitas benda.

4. Membuktikan asal benda maupun jasa yang dihasilkan.

Menurut Cassavera, merek menggambarkan peninggalan kondisional, jika merek wajib menciptakan faedah berbentuk nilai finansial bagi para pemiliknya serta merek wajib selalu bersinggungan dengan suatu produk maupun jasa. Dari perihal tersebut diatas maka produk ataupun jasa menggambarkan wujud nyata dari sesuatu merk. Merek wajib memiliki kriteria tertentu adalah:

1. "Sign";

2. "Which can be represented graphically; and"

3. "Which is capable to distinguishing the goods and service of one undertaking from those of undertakings".

Jadi merek wajib memiliki indikasi yang merepresentasikan secara jelas semacam kondisi sesungguhnya serta sanggup membedakan jika barangnya ialah berbeda dengan barang maupun jasa yang lain.

Schachter mengemukakan kalau merek bagaikan salah satu dari hak kekayaan intelektual merupkaan indikasi pembeda wajib memiliki "single rational basis" merupakan buat melindungi keunikan suatu merek, hingga merek wajib dilindungi bagaikan "species of 
property". Ini memiliki iktikad jika pemilik merek wajib dilindungi pada saat mereknya digunakan oleh pihak lain. Hak yang diberikan pada merek, adalah hak eksklusif guna menghindari pihak ketiga tanpa izinnya untuk mempergunakan merek yang sama ataupun mirip dalam kegiatan perdagangan serta dalam perihal demikian "a likelihood of confusion shall be presumed".

Merek adalah suatu pembeda produk dengan produk lainnya, serta sebagai petunjuk kualitas atas suatu produk selain sebagai pengenal atau identitas yang akan memudahkan konsumen untuk membedakannya. Apabila suatu produk tidak memiliki merek, tentu tidak akan dikenal konsumen, oleh karena itu suatu produk apakah produk itu baik atau tidak, tentu akan memiliki merek. Merek identik dengan produk atau jasa, tetapi bukan ia produk atau jasa itu sendiri. Benda materiil yang dinikmati, sedangkan benda immateriilnya tidak dapat dinikmati secara fisik. Inilah yang membuktikan bahwa merek itu merupakan hak kekayaan intelektual. Kadangkala, yang membuat harga dari suatu produk atau jasa menjadi mahal bukan produk atau jasanya, tetapi mereknya. Karena merek inilah lahir hak atas ciptaan tersebut dan harus diberikan perlindungan hukum yang jelas.

Di Indonesia, pelaku usaha wajib mendaftarkan merek untuk mendapatkan hak merek atas barang atau jasa serta melindungi ciptaannya. Hak atas merek secara langsung mempunyai hak moral dan hak ekonomi, dimana hak moral melindungi kepentingan pribadi dari pencipta seperti perlindungan atas reputasi pencipta, dan hak ekonomi yang memastikan pencipta mendapatkan keuntungan materiil, seperti royalti dan lisensi. Indonesia menganut "asas first to file" atau prinsip konstitutif, dimana kepemilikan hak atas suatu merek diberikan kepada pihak yang mendaftarkannya lebih awal ke Direktorat Jenderal Kekayaan Intelektual (DJKI) atas merek tersebut. Per tahun 2019, dari total 64,1 (enam puluh empat koma satu) juta pelaku Usaha Mikro Kecil Menengah (UMKM) yang ada di Indonesia, hanya 10,632 (sepuluh ribu enam ratus tiga puluh dua) yang mengurusi merek dagangnya ke Direktorat Jenderal Kekayaan Intelektual. Dengan minimnya pengetahuan dan kesadaran pemilik merek akan sistem pendaftaran yang mewajibkan pendaftaran merek sebagai syarat absolut bagi timbulnya hak atas merek, pemilik merek kerap dirugikan dan digunakan mereknya oleh pihak lain tanpa izin.

Penulis membandingkan sistem pendaftaran merek antara Indonesia dan Amerika. Perlindungan merek di Amerika diatur "Lanham Act", dimana merek mengandung setiap nama, simbol, kata atau ketiganya, digunakan oleh masyarakat yang memiliki kemauan. Jika digunakan dalam perdagangan, maka wajib didaftarkan untuk melindungi dan membedakan produk dan jasa berbeda dengan yang lain. Amerika Serikat menganut prinsip penggunaan dalam perdagangan ("use in commerce"), dan tidak mewajibkan pendaftaran merek untuk memperoleh hak atas merek. Pendaftarannya melahirkan hak eksklusif bagi pemilik merek untuk menggunakan merek diluar Amerika Serikat saja. Tidak ada satupun pemilik merek di Amerika Serikat yang memperoleh pendaftaran merek tanpa pemakaian merek dalam 
kegiatan perdagangan barang atau jasa. Richard Wincor dan Irving Mandell menjelaskan bahwa:

"Trademark right arise out of appropriation and use, and the exclusive right to a particular mark belongs to the one who first appropriates and uses it in connection with a particular business. Registration is merely declaratory of title to the mark and therefore does not affect of perfect trademark right".

Dengan demikian, prinsip "use in commerce" memunculkan hak atas merek bagi pemilik merek yang dapat membuktikan kegunaan merek tersebut dalam kegiatan perdagangan. Mengingat ketidaktahuan dan rendahnya kesadaran pelaku usaha di Indonesia untuk mendaftarkan mereknya agar mendapatkan hak atas merek, penulis tertarik untuk membahas perlindungan hukum terhadap pemilik merek tidak terdaftar di Indonesia yang bersifat perlindungan semu, dimana kepastian hukum hanya diraih setelah pendaftaran merek bukan penggunaan dalam perdagangan.

Berdasarkan penjabaran diatas, maka terdapat dua permasalahan yang hendak dibahas yaitu, bagaimana sistem perlindungan merek yang dapat diterapkan bagi pemilik merek tidak terdaftar di Indonesia dan bagaimana sistem perlindungan merek dengan prinsip "use in commerce" yang digunakan di Amerika Serikat.

\section{PEMBAHASAN}

\section{Sistem Perlindungan Merek Dengan Prinsip "Use in Commerce" di Amerika Serikat}

Sebagai salah satu bentuk dari kekayaan intelektual, merek memiliki peran krusial bagi peningkatan dan kelancaran dalam kegiatan perdagangan. Kebutuhan konsumen terhadap daya pembeda yang merupakan jaminan kualitas produk atau jasa dapat dipenuhi dengan "brand image" dari suatu merek. Dari hal-hal tersebut, dapat disimpulkan bahwa merek adalah kekayaan atau aset yang dapat menghasilkan keuntungan. Pentingnya peranan merek inilah menjadi faktor utama mengapa dibutuhkan perlindungan hukum yakni sebagai perlindungan hukum terhadap objek terkait hak-hak peroranganan atau badan hukum. Dalam "Lanham Act", bahwa merek adalah suatu tanda pembeda yang mempunyai berbagai macam variasi seperti nama, gambar, kata, huruf-huruf, angka-angka, bentuk, desain atau kombinasinya, simbol, yang dipergunakan dalam kegiatan perdagangan untuk membedakan barang atau jasa dari produsen dari produsen lainnya. Pada umumnya, Amerika Serikat menganut prinsip yang sama, yaitu prinsip konstitutif atau sistem perlindungan berasaskan "first to file". Tentunya, permohonan perlindungan merek memerlukan syarat permohonan maupun syarat merek itu sendiri. Setelah merek yang diajukan memenuhi syarat-syarat tersebut, maka akan diproses lebih lanjut oleh lembaga "United States Patent and Trademark Office" (USPTO).

USPTO adalah "agency" pada Departemen Perdagangan Amerika Serikat yang mengeluarkan paten terhadap inventor \& usaha akan penemuannya, registrasi merek bagi 
produk dan atau jasa, serta identifikasi kekayaan intelektual. UPSTO memiliki mekanisme untuk membantu proses registrasi. Terdapat dua sistem registrasi pada "Lanham Act" yaitu:

1. Pendaftaran Prinsipal ("Principal Register"), adalah registrasi yang diperuntukan buat seluruh hak yang diatur "Lanham Act".

2. Pendaftaran Tambahan ("Supplemental Register"), adalah registrasi bagi yang tidak bisa didaftarkan pada "principal".

Registrasi tidak menyebabkan perlindungan hak merek, namun hanya menyatakan bahwa hak itu bisa diperoleh melalui suatu penggunaan. Untuk melakukan registrasi setiap pemohon wajib memiliki kegiatan perdagangan yang sah untuk pencatatan. Basis primer yaitu berdasarkan "use in commerce "\& "intent to use in commerce". Untuk memiliki hak merek di Amerika Serikat, pada umumnya pemilik merek harus menjadi yang pertama memanfaatkan jejak dalam perdagangan pada produk atau jasa tertentu. Ada beberapa pengecualian, misalnya, ketika calon pendaftar memiliki pendaftaran yang tidak biasa atau mendaftarkan mereknya sebelum menggunakannya terlebih dahulu atau "intent to use". Dalam proses registrasi merek untuk mendapatkan hak katas merek, USPTO memerlukan tanggal atau jejak pertama kali dimana merek tersebut digunakan dan tanggal jejak pertama kali digunakan dalam kegiatan perdagangan. Bukti produk atau jasa dan usaha yang dapat dikenali wajib dilampirkan dalam registrasi merek.

Untuk produk, "use in commerce" mengacu pada barang yang dijual atau dikirim di Amerika Serikat dalam proses standar pertukaran dengan merek yang idealnya ditunjukkan pada produk atau kemasan, label, dan lain-lain. Mempublikasikan dan mempromosikan material dari produk tersebut pada umumnya adalah contoh yang tidak dapat diterima. Untuk jasa, "use in commerce" mengacu pada jasa yang diperdagangkan di Amerika Serikat. Contoh yang layak dari penggunaan jasa dapat mencakup publikasi dan promosi yang menunjukkan jejak dan mengacu pada jasa yang diakui dalam pendaftaran merek. Contoh penggunaan yang tidak diterima adalah dimana upaya-upaya tersebut mencakup penggunaan simbolis.

Umumnya, "use in commerce" mengacu pada kontribusi produk atau jasa yang melintasi garis negara bagian dengan jalan raya dan transaksi secara eksklusif di dalam suatu negara bagian ("intrastate"). Perbedaan melintasi jalan raya dengan "intrastate" kurang akurat akhir-akhir ini mengingat berevolusinya industri perdagangan yang berbasis daring. Kegiatan perdagangan ke negara-negara lain juga dapat dimasukkan sebagai penggunaan dalam perdagangan. Seorang calon pemilik merek harus mendaftarkan permohonan "intent to use" untuk merek yang belum digunakan. Untuk lintas negara bagian, pencatatan registrasi "intent to use" adalah metode yang lebih aman karena memberikan calon pemilik merek tanggal dokumentasi sebelumnya dan lebih banyak kesempatan untuk memanfaatkan merek sebelum mengirimkan bukti penggunaan ke USPTO. 
Penggunaan dalam perdagangan menjadi dasar aturan bahwa setiap pemilik wajib menyerahkan suatu deklarasi atau pernyataan yang menyatakan lepas dicatatkan ("filing date"), merek digunakan pada perdagangan bila terdapat pengaturan perdagangan antara negara bagian \& perdagangan menggunakan negara lain. Pengertian "use in commerce" tercantum pada Pasal 45 "Lanham Act" yaitu penggunaan merek secara itikad baik pada perdagangan \& secara spesifik, "A mark shall be deemed to be use in commerce."

1. "On goods when,

a. It's placed in any manner on the products or their containers or the displays associated therewith or on the tags or labels affixed thereto, or if the character of the products makes such placement impracticable, then on documents related to the products or their sale, and;

b. The products are sold or transported in commerce".

2. "On services when it's used or displayed within the sale or advertising of sevices and therefore the services are rendered in commerce, or the the services are rendered in additional than one state or within the us and foreign country and also the person rendering the services is engaged in commerce in reference to the services".

Dasarnya, pemohon "intent to use" harus menciptakan suatu arsip yang menyatakan pernyataan berisi suatu keiginan melaksanakan suatu merek menggunakan asas itikad baik. Dinaungan Hukum “Common Law” Amerika Serikat, pemilik merek mempunyai hak merek dalam perdagangan tanpa pendaftaran, melainkan berlandaskan maksud penggunaannya dalam kegiatan praktik perdagangan. Hukum "Common Law" Amerika mengindikasikan bahwa merek dagang adalah hak yang dikembangkan melalui penggunaannya dalam kegiatan perdagangan yang tidak diatur oleh undang-undang. Hak merek dagang "Common Law" telah dikembangkan secara yudisial, dimana skema hak atas merek telah yang diatur oleh hukum negara. Oleh karena itu, pendaftaran tidak menimbulkan hak yang dapat ditegakkan dengan catatan bahwa merek tersebut mempunyai "secondary meaning" yang menjadi pembeda serta dapat dibuktikan hakikat, tempat, waktu, dan penggunaannya dalam perdagangan. Bukti dapat berupa dokumen, pembungkus, label, daftar harga, katalog, foto, periklanan dan pendapat atau testimoni masyarakat. "Secondary meaning" di Amerika Serikat bisa dibuktikan lewat:

1. "direct evidence" alias fakta langsung yaitu melalui kesaksian konsumen ataupun survei konsumen; atau

2. "indirect evidence" alias fakta tidak langsung yaitu penggunaan, jumlah serta teknik pengiklanan, jumlah penjualan pada konsumen, pangsa pasar, fakta terdapatnya kehendak pihak lain untuk meniru merek. 
Registrasi tidak memunculkan hak atas merek, tapi registrasi disini menggambarkan sesuatu pernyataan kalau hak atas merek dapat diperoleh lewat suatu penggunaan. Penggunaan tersebut pula menggambarkan ketentuan dalam pengajuan pendaftaran merek. Permohonan wajib menciptakan suatu pernyataan berisi suatu kemauan melangsungkan suatu merek dengan prinsip "use in commerce". Permohonan dengan prinsip tersebut tidak bisa didaftarkan hingga:

1. Merek tersebut memang dipergunakan dalam perdagangan;

2. Pernyataan yang jelas yang hendak mempengaruhi suatu permohonan;

3. Spesifikasi yang diajukan untuk permohonan.

Selain itu juga dapat ditampilkan bukti pendukung yang diperoleh dari pernyataan di bawah sumpah secara tertulis berdasarkan hukum yang berlaku oleh pemilik merek bahwa mereknya bukan hanya sebagai nama yang bersifat diskriptif. Amerika Serikat mengimplementasikan perlindungan hukum terhadap merek berdasarkan pada praktik dan maksud penggunaan merek tersebut dalam perdagangan. Pada Pasal 43(a) "Lanham Act", mengatur tentang perlindungan bagi merek tidak terdaftar di Amerika, dapat dilakukan oleh negara dengan mengambil tindakan berupa:

"Civil Action,

1. Any person who, on or in connection with any goods or services, or any container for goods, uses in commerce any word, term name, symbol, or device, or any combination thereof, or any false designation of origin, which,

a. Is likely to cause confusion, or to cause mistake, or to deceive affilation, connection, or association of such person, or as to the origin, sponsorship, or approval of his or her goods, services, or commercial activities by another person shall be liable in a civil action by any person who believes that he or she is or likely to be damaged by such act".

"Lanham Act" umumnya menganggap pengguna merek dagang pertama sebagai pemilik yang sah. Perbedaan ini membuat Amerika Serikat berbeda dari banyak negara yang memberikan hak merek dagang kepada pengguna merek pertama. Jadi jika penggunaan merek dagang lebih awal adalah faktor penentu, mengapa perusahaan harus mengajukan permohonan merek lebih awal daripada yang lain mengajukan permohonan merek serupa? Apa perbedaan yang dibuat oleh tanggal pengajuan merek dagang awal? Tanggal pengajuan merek dagang yang lebih awal dapat membuat perbedaan besar. Dalam hal permohonan merek dagang yang diajukan ke USPTO, tanggal pengarsipan yang lebih awal membawa keuntungan substansial dalam hal biaya, prosedur, dan hak substantif. Dengan kata lain, tidak ada alasan yang baik untuk menunggu ke pendaftaran jika pengguna merek tersebut telah memutuskan untuk melanjutkan dengan merek tertentu. 
Pengguna pertama yang dapat menghemat banyak uang dengan mengajukan permohonan merek dagang pengguna sebelum orang lain. Secara umum, USPTO meninjau permohonan merek dagang dalam urutan penerimaannya. Jika dua permohonan merek serupa diajukan oleh dua perusahaan berbeda, permohonan merek dagang yang diajukan sebelumnya akan diperiksa terlebih dahulu. Permohonan yang menunggu keputusan ini akan ditinjau tanpa memperhatikan tanggal penggunaan pertama yang diduga dalam permohonan yang diajukan nanti. Dengan kata lain, pemeriksa tidak membandingkan tanggal penggunaan pertama saat meninjau permohonan merek dagang. Meskipun permohonan merek dagang yang diajukan kemudian menuduh tanggal penggunaan pertama yang lebih awal dari tanggal penggunaan pengguna, tanggal penggunaan yang lebih awal tersebut tidak menjadi masalah bagi pemeriksa. Beban akan ditanggung oleh pemohon berikutnya untuk menentang permohonan merek dagang pengguna.

Untuk perusahaan yang kekurangan sumber keuangan, pertentangan merek dagang seperti itu mungkin tidak akan pernah terjadi. Jadi tanggal pengajuan yang lebih awal menghemat biaya untuk kemungkinan membela oposisi. Di sisi lain, pertimbangkan penghematan biaya karena tidak harus menyerang. Jika pesaing, atau bahkan seorang oportunis, mengajukan permohonan merek serupa bahkan hanya beberapa hari sebelum tanggal pengajuan pengguna, pengguna akan menghadapi biaya dan beban karena harus menentang permohonan merek dagang mereka. Ada juga keuntungan substantif dari tanggal pengajuan merek dagang sebelumnya. Tanggal pengajuan permohonan "intent to use" menjadi tanggal konstruktif untuk penggunaan pertama jika permohonan tersebut telah matang menjadi pendaftaran. Dengan kata lain, undang-undang akan memperlakukan tanggal penerimaan "intent to use" seperti tanggal penggunaan pertama jika merek intent to use berhasil didaftarkan. Ini adalah manfaat yang sangat nyata dan berguna bagi pemilik merek dagang yang ingin mencegah orang lain menggunakan merek serupa.

Permohonan yang diajukan kemudian untuk merek serupa biasanya akan ditangguhkan menunggu hasil dari permohonan yang diajukan sebelumnya. Penangguhan bisa memakan waktu beberapa bulan atau bahkan beberapa tahun. Misalnya, jika permohonan yang diajukan sebelumnya didasarkan pada "intent to use", pemohon tersebut dapat memakan waktu hingga tiga tahun untuk mengajukan pernyataan penggunaan dengan asumsi permohonan mereka diizinkan (yang dapat memakan waktu satu sampai dua tahun jika ada penolakan diatasi). Jadi kerugian utama dari tanggal pengajuan yang lebih lambat adalah keterlambatan pendaftaran yang bisa memakan waktu bertahun-tahun untuk diselesaikan. Sekali lagi, perlu ditekankan bahwa permohonan merek dagang diperiksa oleh USPTO secara umum dalam urutan yang diterima. Oleh karena itu, permohonan yang diajukan kemudian akan menimbulkan risiko berikut:

1. Penangguhan menunggu hasil dari permohonan yang diajukan lebih awal untuk merek yang sama; 
2. Penundaan dalam pendaftaran bahkan jika tanggal penggunaan pertama Pengguna lebih awal dari pada permohonan yang diajukan sebelumnya;

3. Biaya karena harus menentang permohonan yang diajukan sebelumnya.

Dari penjelasan diatas, dapat dipahami bahwa dengan tidak mewajibkan pendaftaran, maka merek yang digunakan dapat diberikan perlindungan hukum jika dapat membuktikan bahwa merek tersebut telah digunakan dalam kegiatan perdagangan ("use in commerce") atau hendak akan digunakan dalam kegiatan perdagangan ("intent to use in commerce").

\section{Perlindungan merek yang dapat diterapkan bagi pemilik merek tidak terdaftar di Indonesia}

Perlindungan merek bagi pemilik merek tidak terdaftar di Indonesia yang dapat digunakan terhadap pemilik merek tidak terdaftar di Indonesia didasari oleh fungsi kepentingan yang dikemukakan oleh Rudolf von Jhering:

"Dimana suatu hukum tidaklah murni dari jiwa bangsa yang sesuai dengan jiwa bangsa hukum tersebut berkembang serta tumbuh menjadi hukum yang ideal apabila cocok dengan jiwa bangsa serta memiliki unsur- unsur yang cocok dengan jiwa bangsa."

Tidak hanya itu, teori keadilan yang dikemukakan oleh John Rals yang berakar dari kritiknya terhadap "Average Utilitianirisme" kepunyaan John Stuart yaitu:

"Pengorbanan adalah sesuatu hal yang lumrah demi kepentingan umum, namun tidak bisa dibenarkan apabila pengorbanan tersebut pertama kali dimohonkan dari orangorang yang kurang beruntung."

Dalam rangka melindungi pemilik merek tidak terdaftar dan pelaku UMKM dengan terdapatnya permohonan pendaftaran merek yang digunakan oleh pihak lain tetapi belum didaftarkan, ada usulan dari ahli-ahli hukum merek ialah dengan mengedepankan prinsip proteksi kombinasi atau perlindungan hukum gabungan. Sistem proteksi gabungan merupakan sistem proteksi yang didasarkan atas sistem deklaratif serta sistem konstitutif. Mr. E. A. Van Nieuwenhoven Helbach:

"Hukum merek dari bermacam negeri memahami dua metode demi mendapatkan hak atas merek, pertama, pemakai awal serta pendaftar awal."

Tiap sistem proteksi mempunyai keuntungan serta kerugiannya masing-masing. Oleh sebab itu, tidak mengherankan bilama hendak diterapkannya proteksi gabungan, ialah sesuatu proteksi yang membagikan akibat hukum baik kepada penggunaan ataupun pendaftaran bermacam ragam dapat terjalin, jika dengan penggunaan awal dapat menghasilkan hak atas merk, serta pendaftaran ialah wujud penggunaan, atapun ialah peranan bagaikan bukti-bukti dari persyaratan penerapan hak khusus tersebut. 
Apabila dilihat dari sisi pihak yang menganut proteksi pendaftaran yang menghasilkan hak, hingga penggunaan bisa mengambil peranan bagaikan ketentuan buat kelangsungan dari pada hak yang diperoleh melalui proses pendaftaran, maupun bagaikan wujud tujuan yang jelas dimana penggunaan bagaikan faktor tambahan terciptanya hak. Bergantung dari apakah pendaftaran bisa ataupun tidak menghasilkan hak, yang merupakan perbandingan antara perlindungan konstitutif ataupun perlindungan deklaratif. Sesungguhnya, objektif dari pemakaian prinsip pendaftar awal adalah memastikan kepastian hukum yang sangat diperlukan untuk pelaku usaha, akan tetapi pemakaian sistem pendaftar awal pula tidak menutup mungkin atas kemampuan penyalahgunaan hak tersebut lewat pemakaian celah hukum dalam sistem registrasi merek secara konstitutif.

Apabila dikomparasikan dengan sistem pemakai awal ataupun "first to use", registrasi suatu merek hanya membagikan sesuatu dugaan hukum jika terdapat oknum mengatasnamakan dirinya dari suatu merek itu didaftarkan diduga menurut hukum sejatinya diakui bagaikan pengguna awal di Indonesia serta karenanya pemilik dari merek yang bersangkutan. Namun, apabila ada pihak lain yang dapat membuktikan bahwa ialah pengguna awal, hak pendaftar dikira tidak berlaku karena pihak yang dapat membuktikan bahwa ialah pengguna awal tersebut yang diakui oleh hukum sebagai pihak yang berhak atas suatu merek.

Dalam rangka melindungi pihak yang dirugikan atas sesuatu registrasi merek, UndangUndang Nomor 20 tahun 2016 tentang Merk dan Indikasi Geografis memberikan peluang untuk pihak yang merugikan untuk mengpermohonankan upaya hukum. Dalam undangundang tersebut, terdapat suatu mekanisme upaya hukum terhadap pemilik merek yang tidak terdaftar apabila terdapat tindakan- tindakan yang termasuk dalam Pasal 20 serta Pasal 21.

Upaya hukum tersebut adalah berbentuk pengajuan gugatan pembatalan merek yang sudah terdaftar yang melanggar hak dari pemilik merek tidak terdaftar dengan ketentuan pemilik merek tersebut mengajukan permohonan registrasi kepada Menteri. Jangka waktu pengajuan gugatan hanya sanggup diajukan dalam jangka waktu lima tahun semenjak bertepatan pada registrasi merek, ataupun tidak terbatas waktu apabila ada faktor itikad tidak baik ataupun merek yang bersangkutan berlawanan dengan ideologi negara, peraturan perundang- undangan, moralitas, agama, kesusilaan, serta kedisiplinan umum. Pemilik merek yang tidak terdaftar yang dalam tentang ini menggambarkan pemakai awal sesuatu merek maupun menggambarkan pihak yang semestinya dilindungi, sanggup mengajukan upaya pembatalan merek meski telah jatuh tempo waktu lima tahun semenjak registrasi merek dengan dalih jika merek terdaftar tersebut didaftarkan atas permohonan yang beritikad tidak baik serta tidak ada kegunaannya dalam perdangangan.

Pembatalan merek sendiri menggambarkan suatu prosedur yang ditempuh oleh salah satu pihak untuk mencari serta memberantas eksistensi registrasi dari sesuatu merek dari Daftar Umum Merek (DUM) maupun membatalkan keabsahan hak berlandaskan sertifikat merek. Merek terdaftar masih bisa dibatalkan pendaftarannya, apabila menurut dalil yang 
layak merek tersebut didaftar dengan tidak memenuhi dasar absolut ("absolute grounds") maupun dasar relative ("relative grounds"). Apabila melihat pada ada maupun munculnya kerugian yang berlangsung atas perbuatan tersebut, sehingga bisa dikategorikan bahwasanya kegiatan registrasi yang dilandasi dengan itikad tidak baik ialah satu buah wujud perbuatan melanggar hukum sehingga pihak yang dirugikan adalah pemilik merek yang semestinya dapat mengajukan gugatan ganti rugi dengan dalil perbuatan melanggar hukum sebagaimana Pasal 1365 BW.

Doktrin pendaftaran awal maupun "first to file principle", siapa pendaftar awal dikira memiliki hak yang lebih unggul serta lebih utama dari pemilik merek yang ada, cocok dengan asas "prior in filing", namun berbarengan dengan itu ditegakkan doktrin pemakai awal ataupun "first to use system", apabila bisa memverifikasi jika ia pemakai awal yang sebetulnya dikira pemilik sangat unggul haknya bila seorang bisa meyakinkan peran yang utama pada asas "prior user has a better right" ataupun pemakai awal memiliki hak yang lebih baik dari pendaftar pertama. Lingkup proteksi hukum yang diberikan kepada pemilik merek, meliputi:

1. Melindungi pemakaian hak eksklusif merk, meliputi:

a. Mempergunakan ciri merk bagaikan logo, label ataupun foto dalam pesan menyurat, pada benda ataupun jasa, pada kemasan ("packaging") dalam advertensi ataupun promosi.

2. Menikmati secara eksklusif perwujudan yang lahir dari merk, meliputi "goodwill" ataupun "well- known", reputasi besar, sumber asal, sentuhan kulturan serta sentuhan keakraban.

3. Melindungi hak eksklusif mempergunakan merk bagaikan perlengkapan eksploitasi mendapatkan keuntungan dalam perdagangan, meliputi:

a. Memasarkan benda ataupun jasa dalam perdagangan nasional, regional, serta global;

b. Menaruh benda yang dilindungi hak merk, asal tidak berlawanan dengan syarat dominasi serta spekulasi buat menaikkan harga.

\section{PENUTUP}

Syarat merek di Amerika Serikat memberikan proteksi hukum yang lebih baik terhadap pemilik merek terdaftar. Perlindungan hukum merek di Amerika Serikat tidak diberikan berlandaskan pendaftaran namun melaui pemakaian yang didasarkan bahwa pemakaian dalam praktik itu wajib sesuai dengan persyaratan jika merek tersebut wajib "use in commerce" maupun "intent to use in commerce". Sistem perlindungan merek di Indonesia hendaknya mengadopsi proteksi merek di Amerika Serikat, yakni memberikan proteksi bersumber pada dua sistem, yakni lewat perlindungan merek bersumber pada penggunaan serta pendaftaran. 
Proteksi merek yang berlaku di Indonesia hanya diberikan sesudah pendaftaran, sehingga proteksi hanya bertabiat perlindungan semu karena kepastian hukum hanya tercapai sesudah pendaftaran, serta pendaftar yang tidak baik juga dilindungi pula dalam praktik memberikan perlindungan berlandaskan penggunaan merek yang pertama. Ada alternatif model proteksi hukum merek yang dapat memberikan proteksi terhadap merek- merek yang belum didaftarkan. Yaitu model proteksi hukum gabungan antara prinsip perlindungan pendaftar pertama ("first file") serta prinsip pemakai pertama ("first to use"). Dimana pihak yang memakai memperoleh prioritas proteksi haknya atas merek, sejauh bisa membuktikan jika ialah pemakai pertama dan pendaftar pertama sudah mengenali keberadaannya, disamping itu pendaftar pertama juga mendapat prioritas perlindungan haknya atas merek sepanjang dapat membuktikan bahwa tidak terdapatnya itikad tidak baik dari pihaknya terhadap pendaftaran merek tersebut.

Model perlindungan hukum di Amerika Serikat juga ikut melindungi merek-merek yang tidak terdaftar sejauh merek maupun ciri yang belum terdaftar tersebut digunakan dalam perdagangan. Adanya perbuatan pendaftaran merek yang digunakan orang lain tetapi belum didaftarkan merupakan salah satu implikasi maupun celah hukum atas prinsip perlindungan pendaftar pertama (“first to file”) yang dianut oleh Indonesia.

\section{DAFTAR PUSTAKA}

\section{Buku}

Abdul Kadir Muhammad, Kajian Hukum Ekonomi Hak Kekayaan Intelektual, Bandung: Citra Aditya, 2001.

Achmed Zen Purba, Hak Kekayaan Intelektual Pasca TRIPs, Bandung: Alumni, 2005.

Tim Lindsey, Hak Kekayaan Intelektual (Suatu Pengantar), Bandung: Alumni, 2006.

Cassavera, Kasus Sengketa Merek di Indonesia, Yogyakarta: Graha Ilmu, Cetakan Pertama, 2009.

H. OK. Saidin, Aspek Hukum Hak Kekayaan Intelektual (Intellectual Property Rights), Jakarta: Raja Grafindo Persada, 2015.

Rahmi Janed, Hukum Merek (Trademark law) dalam Era Globalisasi Dan Integrasi Ekonomi, Jakarta: Kencana Prenadamedia, 2015.

Sri Sayekti, Tinjauan Yuridis Perlindungan Merek yang belum terdaftar di Indonesia, Majalah Ilmiah Pawiyatan, Edisi Khusus, Juli 2015.

Wincor, R., Mandell, I., dan Sloan, I. J, Copyright, Patents, and Trademarks: The Protection of Intellectual and Industrial Property, New York: Oceana Publications, 1980.

\section{Jurnal}

Angia Clara Citra dan Suci Paramitasari Syahlani, "Efek Merek Domestik Vs Asing Dan Informasi Country-Of-Origin Terhadap Persepsi Dan Sikap Konsumen: Studi Perilaku 
Konsumen Pada Produk Susu Olahan", Jurnal Ekonomi dan Bisnis Indonesia, Volume 23 No. 2, 2008.

Ariandika Herviandi, Etty Susilowati, dan Rinitami Njatrijani, "Optimalisasi Perlindungan Hukum Terhadap Pendaftaran Merek Dagang Di Negara Lain (Kajian Perlindungan Hukum Merek Kopi Arabika Gayo)", Diponegoro Law Journal, Volume 6 No. 1, 2017.

Delila Pritaria Cantika, "Pembatalan Hak Merek Yang Telah Dijadikan Jaminan Fidusia", Jurnal Yuridis, Volume 5 No. 1, 2018.

Lee Ann dan W. Lockridge, “Abolishing State Trademark Registrations”, Cardozo Arts \& Entertainment Law Journal, Volume 29 No. 597, 2011.

Mark McKenna, "Trademark Use and The Problem of Source", University of Illinois Law Review, Volume III, 2009.

Mohammad Amar Abdillah, "Perlindungan Hukum Pemilik Merek Tidak Terdaftar Atas Tindakan Pendaftaran Mereknya Oleh Pihak Lain Ditinjau Dari Asas Itikad Baik", Jurist-Diction, Volume 2 No. 2, 2019.

Rika Ratna Permata dan Muthia Khairunnisa, "Perlindungan Hukum Merek Tidak Terdaftar Di Indonesia", Jurnal Opinio Juris, Volume 19 No. 2.

Sulastri, Satino, Yuliana Yuli W, "Perlindungan Hukum Terhadap Merek (Tinjauan Terhadap Merek Dagang Tupperware Versus Tulipware)", Jurnal Yuridis, Volume 5 No. 1, 2018.

Stuart Graham, Galen Hancock, Alan Marco, Amanda Fila Myers, "The UPSTO Trademark Case Files Dataset: Description, Lessons, and Insight" Journal of Economics \& Management Strategy, Volume 22 Issue 4, 2013.

Yudhi Priyo Amboro dan Steven, "Tinjauan Yuridis Perlindungan Hak Merek Dalam Perspektif Perbandingan Hukum Indonesia Dan Amerika Serikat", Journal of Judical Review, Volume 17 No. 2, 2015.

\section{Peraturan Perundang-Undangan}

The Lanham Act 1946

Kitab Undang-Undang Hukum Perdata

Kitab Undang-Undang Hukum Dagang

Undang-Undang Republik Indonesia Nomor 20 Tahun 2016 tentang Merek dan Indikasi Geografis

\section{Pranala Luar}

Elsa Catrina (Kompas Cyber Media), "Dari 64,1 Juta UMKM, Baru 10.632 Yang Mengurus Merek Dagang.", https://money.kompas.com/read/2020/07/17/161100826/dari-64-1juta-umkm-baru-10.632-yang-mengurus-merek-dagang, diakses pada 14 Oktober 2020, Pukul 07.15 WIB. 